\title{
A Comparative Study of the Effect of Using RO Water on Zinc and Copper Level and its Effect on the Level of Hemoglobin in Pregnant Women
}

\author{
Riyadh Hussein Wally \\ Middle Technical University, Technical institute - Kut-Iraq. \\ Corresponding Author: aalaatad@yahoo.com.
}

\begin{abstract}
This study was conducted in the department of pathological analysis in Al-Kut technical institute of Iraq, were the total dissolved solid (TDS) and the level of zinc and copper trace elements measured for tap water and reverse osmosis RO water in several areas of Al-Kut city. Two groups of healthy pregnant women attending maternity health centers in Al-Kut city were selected for this study during the week 24-28 of gestation, aged between 20-40 years. The first group consisted of 55 pregnant women using tap water as drinking source and the second group also included 55 pregnant women using RO water as drinking source. The blood samples were collected from both groups and hemoglobin, zinc and copper levels were measured in both groups. The study showed a highly decreased in the level of TDS(15 \pm 5$)$, zinc $(1 \pm 0.1)$ and copper $(1 \pm 0.2)$ of RO water in comparison with tap water were $\operatorname{TDS}(680 \pm 32)$, zinc $(5.4 \pm 2.1)$ and copper $(8.7 \pm 3.1)$ also study show significance decrease in hemoglobin $(10.8 \pm 1.1)$, zinc $(7.8 \pm 1.8)$ and copper $(9.1 \pm$ 2.1) levels in pregnant woman who drinking RO water in comparison with woman drinking tap water were the level of hemoglobin(11.3 \pm 1.3$)$, zinc(9.4 \pm 2.6$)$ and copper(10.9 \pm 3.6$)$.
\end{abstract}

[DOI: 10.22401/JUNS.21.1.08]

Keywords: Copper; zinc; RO water; pregnant women; hemoglobin.

\section{Introduction}

The increase of pollution in the environment, especially in drinking water sources and the change in lifestyles led to use several methods to obtain drinking water free from pollution and the common method used in Iraq is using the reverse osmosis RO method to obtain water free from salt and pollutants [1]. Reverse osmosis RO is the name given to the process of purification of water by the transfer the contamination water through a semi-porous membrane based on the osmotic property [2], The normal total dissolved solids (TDS) level of tap water in Al-Kut city approximately between $620 \mathrm{mg} / \mathrm{l}$ to $870 \mathrm{mg} / \mathrm{l}$ and the TDS of drinking water according to national field manual must be below $500 \mathrm{mg} / 1$ [3], while the TDS of traditional RO water approximately between $10-20 \mathrm{mg} / \mathrm{l}$, this means there are very low trace element, were the trace element are very important to human body especially pregnant woman because enter in the structure of the body of mother and fetus and help it to perform its vital functions. Trace element concentration is almost constant from one person to another and found in the human body by less than $50 \mathrm{mg} / \mathrm{kg}$ [4], any deficiency in one of these elements causes a defect to be treated mainly by taking this element from water or food. These elements play a important role in the biochemistry of the body [5].

Copper is absorbed from the bowel and connected with the albumin or formation complex bonding with histidine amino acid and then transferred to the liver and stored in form copper protein, also small part of copper connected with albumin and circulates in the blood called transcupein, most of it is incorporated into ceruloplasmin, which is made in the liver [6]. Copper is a mineral element necessary for the human body in small amounts and cannot be made by the body where it needs to be obtained from water and food [7]. It was found as a necessary element in the blood and play important role in metabolism where it's the third most important element in the body behind iron and zinc and found normally in the human body in concentration between 75 and $100 \mathrm{mg} / \mathrm{l}$, while if exceeds above the normal level, it becomes toxic [8]. This component plays a vital role in the formation of bones, red blood cells, and hemoglobin and helps in the absorption and utilization of iron[9], as well as it affects the generation of energy in the body, regulate 
heartbeat and blood pressure and wound healing process[10]. If the body does not get enough of it, the production of hemoglobin decreases and hypochromic-microcytic anemia results[11].

Zinc absorbed from intestine and transport in blood by connected to albumin and another small part which connected to transferrin [12], it's the second trace element most abundant following iron in human body that needed for good health and essential factors to good life processes and basic body functions[13]. It requires for more than 300 different enzymes as a catalyst for its function and present in all cells of the body, were act as enzyme cofactor to synthesizes the heme part of hemoglobin and its deficiency cause anemia [14]. It is needed for the body's immune system to right work. It plays a role in cell division, cell growth, wound healing, and the breakdown of carbohydrates. It is also needed for the senses of smell and taste. During pregnancy, infancy, and childhood the body needs zinc to grow and develop properly. Zinc also enhances the action of insulin [15]. Zinc deficiency inhibits digestion and absorption, leading to diarrhea, which in turn increases poor malnutrition, and weakens the responses of the immune system, which increases the risk of infection [16]. Zinc deficiency complications also include damage to the nervous system and brain and causes a delay in cognitive performance, also cause negatively affects on representation of vitamin $\mathrm{E}$ because its play important role in it, therefore accompanied by symptoms of vitamin E deficiency [17], and affects the lack of zinc in the work of thyroid hormone and metabolic rate in the body [18], also zinc deficiency causes a slow healing of wounds. In addition to the above, the symptoms of zinc deficiency also include delayed growth and sexual maturity, hair loss and can cause loss of weight. [19].

Copper and zinc are widely spread in nature, were zinc found in underground and river water due to deposits containing minerals or from industrial pollution [20]. Copper may be present in high concentration in tap water due to the corrosion of some parts of copper conduction pipes [21]. The percentage of copper and zinc is high in the case of galvanized steel coatings pipe that made from zinc and copper [22]. Because zinc and copper is co-factor for many enzymes involve in iron metabolism, the symptoms of copper and zinc deficiency in pregnant woman have been detected with anemia or iron deficiency anemia [23]. Zinc and copper are essential for the fetal development and growth. [24].

\section{Data Analysis}

The results were entered into the computer and the statistical analysis was performed using the SPSS program where the results expressed as mean \pm standard deviation.

\section{Materials and Methods}

This study was conducted in the department of pathological analysis in Al-Kut city of Iraq, were total dissolved solid (TDS) determined by use TDS meter and the level of zinc and copper were measured in the tap water and traditional RO water from several areas in Al-Kut city and the values evaluated depending on WHO criteria [25]. Study include two group of healthy pregnant women who attending the health centers for maternity care in Al-Kut city during the week 24-28 of gestation, first group include 55 pregnant woman using $\mathrm{RO}$ water as drinking water, second group also include 55 pregnant woman using tab water. Blood samples were collected in metal free container (plan tube with white color cover) to prepare serum and another part collected in EDTA tubes(tube with purple color cover) to prepare anticoagulated blood. Serum was separated from whole blood by use centrifugation at $3000 \mathrm{rpm}$ for $10 \mathrm{~min}$ and put in another metal free plain tube. EDTA blood were used to determined hemoglobin level by use cyanomethemoglobin method [26], plain tube serum were used to determination zinc and Copper by Atomic Absorption Spectrophotometer [27].

\section{Results}

The comparative of TDS between tap water and RO water show a very low level $(15 \pm 5)$ of $\mathrm{RO}$ water in compared with tap water $(680 \pm 30)$ Table (1), Fig.(1). 
Table (1)

Comparison the of water TDS values between tap water and RO water.

\begin{tabular}{||c||c|c|c||c||}
\hline \hline Parameter & Normal level( WHO criteria) & $\begin{array}{c}\text { Tap water level } \\
\text { mean } \pm \text { SD }\end{array}$ & $\begin{array}{c}\text { RO water level } \\
\text { mean } \pm S D\end{array}$ & $P$-value \\
\hline \hline TDS (mg/l) & Less than 500 & $680 \pm 32$ & $15 \pm 5$ & $\mathrm{P}<0.0001$ \\
\hline
\end{tabular}

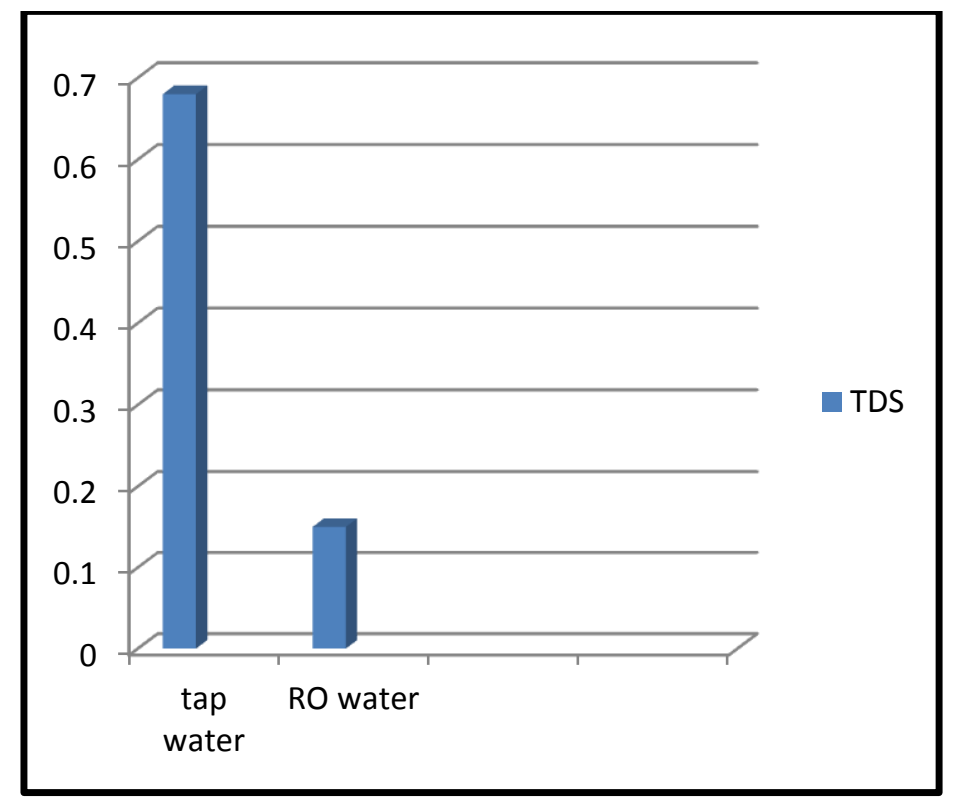

Fig.(1): Graphical comparison the mean value of water TDS between tap and RO water.

In comparative between tap drinking water and RO water parameter, the level of zinc $(0.1 \pm 0.01)$ in $\mathrm{RO}$ water is lower than tap water $(0.54+0.21)$ also the level of copper $(0.1 \pm 0.02)$ in $\mathrm{RO}$ water is lower than tap water $(0.87 \pm 0.31)$ Table (2), Fig.(2).

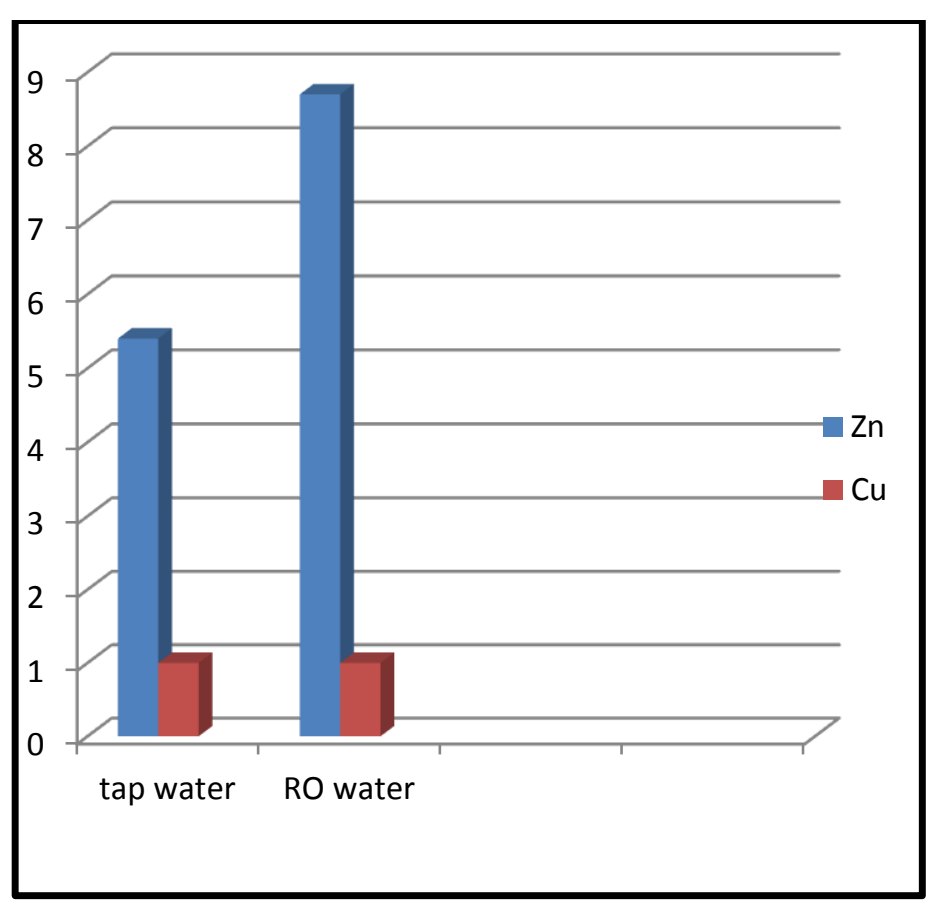

Fig.(2): Graphical comparison the mean values of zinc and copper between tap water and $\mathrm{RO}$ water. 
Study also showed a decrease in level of hemoglobin $(10.8 \pm 1.1)$, zinc $(7.8 \pm 1.8)$ and copper $(9.1 \pm 2.1)$ with pregnant woman use RO drinking water in compared with woman use tap drinking water were the level of hemoglobin $(11.3 \pm 1.3)$, zinc $(9.4 \pm 2.6)$ and copper (10.9 \pm 3.6$)$ Table (3), Fig.(3).

Table (3)

Comparison of prevalence of $\mathrm{Hb}, \mathrm{Zn}$ and $\mathrm{Cu}$ between tap water and $\mathrm{RO}$ water pregnant women.

\begin{tabular}{|c|c|c|c|c|}
\hline Parameter & $\begin{array}{c}\text { Normal value } \\
\text { mean } \pm S D\end{array}$ & $\begin{array}{l}\text { Tap water woman } \\
(n=55) \text { mean } \pm S D\end{array}$ & $\begin{array}{l}R O \text { water woman } \\
(n=55) \text { mean } \pm S D\end{array}$ & $P$-value \\
\hline $\mathrm{Hb} \mathrm{gm} / \mathrm{dl}$ & $11.5-16.5$ & $11.3 \pm 1.3$ & $10.8 \pm 1.1$ & 0.33 \\
\hline Zn mg/l & $6.0-11.0$ & $9.4 \pm 2.6$ & $7.8 \pm 1.8$ & 0.55 \\
\hline Cu mg/l & $70-150$ & $10.9 \pm 3.6$ & $9.1 \pm 2.1$ & 0.48 \\
\hline
\end{tabular}

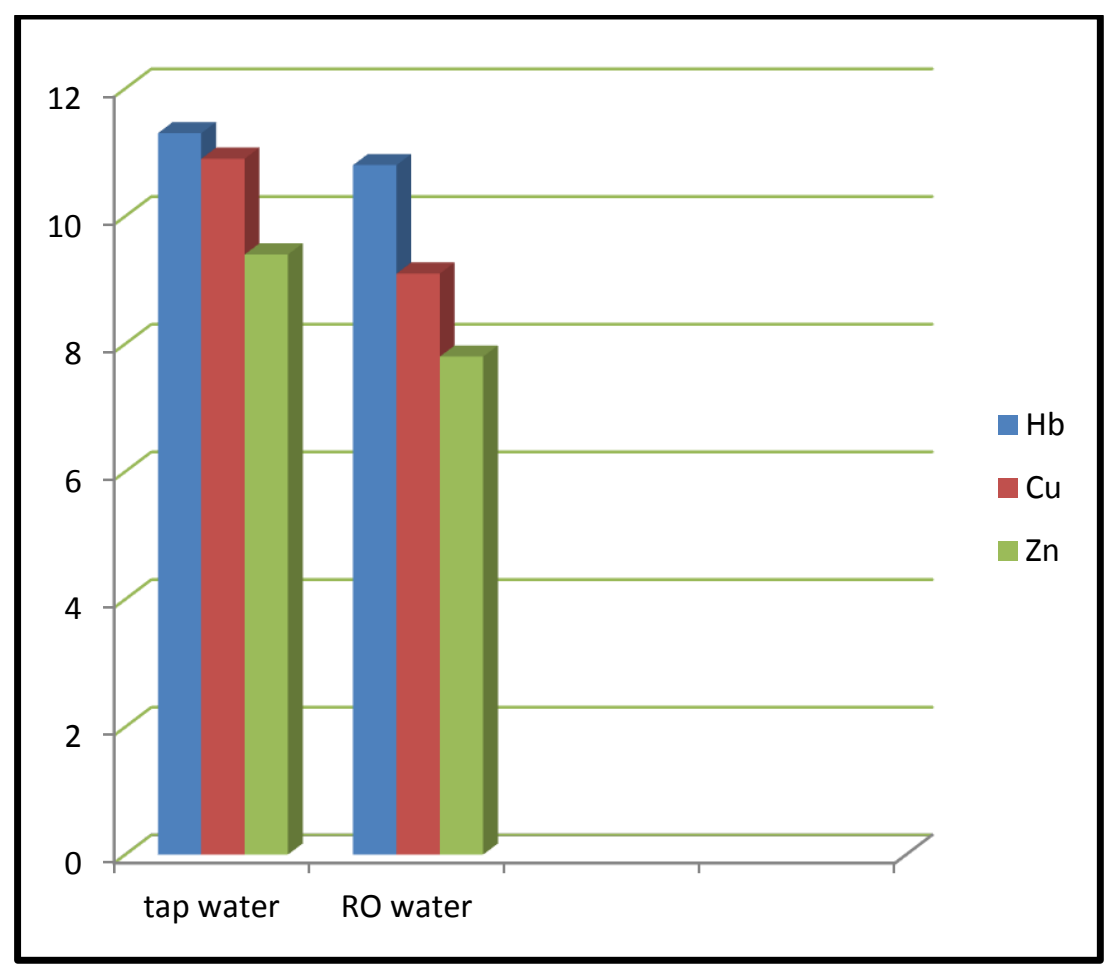

Fig.(3): Graphical comparison the mean values of $\mathrm{Hb}$., $\mathrm{Zn}$ and $\mathrm{Cu}$ between tap water and $R O$ water.

\section{Discussion}

Drinking water is the main source of salts and essential elements of the body and any deficiency of these salts and elements in drinking water will lead to imbalance in the distribution of these salts and elements in the body, were continuous uses of RO water as a main source of drinking water even in cooking cause deficiency in an essential element in body such as zinc and copper. The study showed a significant decrease in the level of TDS in RO water lead to a significant reduction in the level of copper and zinc elements in this type of water. Since this water is used by a large part of people, including pregnant women, it was found through this study there is a significant reduction in the level of zinc and copper which cause significantly reduced in the level of hemoglobin in pregnant women who depend on RO water when compared with pregnant woman depending on tap water as drinking source with consider the pregnant women need to more amounts of these elements because of the presence of its fetus, which also needs these elements [28]. 
Copper is a component of many enzymes involved in hemoglobin synthesis and metabolism including ceruloplasmin which has a major role in iron metabolism and converting ferrous iron to ferric, cytochrome c oxidase which has two groups of heme and two copper atoms that stimulates the reduction of oxygen to water, superoxide dismutase which possesses both copper and zinc, and has a major role as antioxidant defense, dopamine beta hydoxylase has an important role in catecholamine-metabolism, any deficiency in copper cause deficiency in this enzymes were cause hypochromic-microcytic anemia [29]. A number of studies were carried out on laboratory animals to show the effect of copper on hemoglobin found a decrease in absorption of iron from the intestines and accumulation of iron in the liver and nonrelease from cells to plasma was [30]., while zinc play an important role as enzyme cofactor in synthesis of heme moieties of haemoglobin which take place in immature erythrocytes such as d-aminolevulenic acid dehydratase enzyme and carbonic anhydrase, therefore many studies reported a decreased in zinc level and carbonic anhydrase activity of erythrocytes related with anemia [31].

\section{Conclusion}

Prevalence of anemia among pregnant women increases in case of dependence on $\mathrm{RO}$ water as main source to drinking water, where the level of trace elements zinc,copper and other elements such as iron is very low, which affects the process of manufacture of hemoglobin in blood of pregnant women.

\section{References}

[1] Bodalo S.A., Gomez C., Gomez G.F., Maximo M., and A.M. Hidalgo M. "Application of reverse osmosis membrane to reduce pollutants present in industrial waste water", Desalination, 155 pp. 101108, 2008.

[2] Bryan, T., "Reviews about Reverse Osmosis System". Blog. Retrieved 10 August 2017. pp. 218-236, 2009.

[3] USGS, "National field manual for the collection of water-quality data, techniques of water-resources investigations",
Book 9, handbooks for water-resources investigations, pp. 1539-1548, 2015.

[4] WHO, "Trace elements in human nutrition and health". Geneva, WHO press, 72-104, 2010.

[5] Prasad A. S., "Trace Elements in Human Health and Disease", Vol. 1, Accademic, pp.98-108, 2006.

[6] Linder M.C., "Nutritional biochemistry of copper, with emphasis on the perinatal period", Biochemical Aspects of Human Nutrition, Trivandrum, Kerala, India: Research Signpost: pp. 143-179, 2010.

[7] Stern B.R. et al, "Copper And Human Health: Biochemistry, Genetics, And Strategies for Modeling Dose-Response Relationships", Journal of Toxicology and Environmental Health, Part B, 10:157-222, 2007.

[8] Kempson I.M., Skinner W.M. and Kirkbride K.P., "The occurrence and incorporation of copper and zinc in hair and their potential role as bioindicators", A review Toxicol Environ Health. B. Crit. Rev, 10:611-22, 2007.

[9] ATSDR, "Toxicological profile for copper (draft for public comment)", Atlanta, GA, US Department of Health and Human Services, Public Health Service, Agency for Toxic Substances and Disease Registry (Subcontract) No.205-1999-00024, 2002.

[10] Rinaldi A.C., "Meeting report: copper research at the top", Biometals, 13:9-13, 2000.

[11] Sebahat T., Aziz P., Murat I., Gunfer T., Gulten E., Mevlut B., Yasin K.T., and Osman G., "Interaction between anemia and blood levels of iron, zinc, copper, cadmium and lead in children", Indian J. Pediatr, 74:827-30, 2007.

[12] Cousins R.J., Liuzzi J.P. and Lichten L.A., "Mammalian zinc transport, trafficking, and signals. J.Biol. Chem, 281:24085-9, 2006

[13] Prashanth L., Kattapagari K. K., Chitturi R. T., Baddam V. R. and Prasad L. K., "A review on role of essential trace elements in health and disease", Journal of NTR University of Healt Sciences.; 4:75-85, 2015. 
[14] Das M. and Das R., "Need of education and awareness towards zinc supplementation: a review", International Journal of Nutrition and Metabolism, 4(3):45-50, 2012.

[15] Jeejeebhoy K., "Zinc: an essential trace element for parenteral nutrition. Gastroenterology", 137(5) (suppl): S7-S12, 2009.

[16] Bogden J.D., "Influence of zinc on immunity in the elderly", J Nutr Health Aging.; 8:48-54, 2004.

[17] Osredkar J., Sustar N., "Copper and zinc, biological role and significance of copper/zinc imbalance", J. Clinic Toxicol.; S3, 001, 2011.

[18] Napolitano G., Palka G., Lio, S.; Bucc I., De Remigis P. and Stuppia L. et al, "Is zinc deficiency a cause $o$ fsubclinical hypothyroidism in Down syndrome? Ann Genet; 33:9-15, 2011.

[19] Hambidge M., Krebs N.F., "Interrelationships of key variables of human zinc homeostasis: Relevance to dietary zinc requirements", Annu Rev Nutr, 21:42 52, 2011

[20] Kavitha R. and Elangovan K., "Review article on Ground water quality characteristics at Erode district", India of I.J.E.S., 1(2), 2010.

[21] Merkel T.H. and Pehkonen S.O., "General corrosion of copper in domestic drinking water installations: Scientific background and mechanistic understanding" Corros. Eng. Sci. Technol. 41:21-37, 2006.

[22] Brandi N., Clark S., Vaughn M. and Marc A., "New source of lead in drinking water identified: Galvanized steel pipe coating" 20(1), 3-18, 2008.

[23] Ma A.G., Chen X.C., Xu R.X., Zheng M.C., Wang Y. and Li J.S., "Comparison of serum levels of iron, zinc and copper in anaemic and non-anaemic pregnant women in China", Asia Pacific J Clin Nutr; 13(4), 348-352, 2004.

[24] Halfdanarson T. R., Kumar N., Li C. Y., Phyliky R. L., and Hogan W. J., "Hematological manifestations of copper deficiency: a retrospective review", European Journal of Haematology, 80(6), 523-531, 2008.
[25] World Health Organization, "drinkingwater background document for development of guidelines for drinkingwater quality", vol 2. World Health Organization, Geneva, pp 1-10, 2003.

[26] Van K. E.J. and Zijlstra W.G., "Standardization of hemoglobinometry. II. The hemoglobincyanide method", Clin. Chim. Acta, 6, 538, 2002.

[27] Welz B,and Sperling M., "Atomic Absorption Spectrometry", 3th ed, VHC, Weinheim, 2005.

[28] Black, R.E. "Micronutrients in pregnancy, Br J Nutr; 85: Supp 2: 193197, 2001.

[29] Halfdanarson T.R., Kumar N., Li C.Y., Phylik R.L. and Hoga W.J., "Hematological manifestations of copper deficiency: aretrospective review", EuJ Haematology, 80(6):523-531,2008.

[30] Gregg X.T., Reddy V, Prchal J.T., "Copper deficiency masquerading as myelodysplastic syndrome", J. of Blood, 100(4), 1493-1495, 2002.

[31] Esbaugh, A.J. and Tufts, B.L.(2006). "The structure and function of carbonic anhydrase isozymes in the respiratory system of vertebrates. Resp. Physiol. Neurobiol; 154:185-198. 